\title{
The proof is in the pudding: crop isotope analysis provides direct insights into agricultural production and consumption
}

\author{
Amy K. Styring ${ }^{1}$, Corina Knipper ${ }^{2}$, Nils Müller-Scheeßel ${ }^{3}$, Gisela Grupe ${ }^{4}$ \\ \& Amy Bogaard 5 .
}

${ }^{1}$ Institut für Archäologische Wissenschaften, Goethe-Universität Frankfurt, IG-Farben-Haus, Norbert-Wollheim-Platz 1, 60629 Frankfurt am Main, Germany. +49 (0)69 79832091. styring@em.uni-frankfurt.de

${ }^{2}$ Curt-Engelhorn-Zentrum Archäometrie gGmbH, D6, 3, 68159 Mannheim, Germany. +49

(0)621 2938978. corina.knipper@cez-archaeometrie.de

${ }^{3}$ Institut für Ur- und Frühgeschichte, Christian-Albrechts-Universität zu Kiel, Johanna-

Mestorf-Strasse 2-6, 24118 Kiel, Germany. +49 (0)431 880 2067. nils.muellerscheessel@ufg.uni-kiel.de

${ }^{4}$ LMU München Biozentrum Martinsried, Grosshaderner Str. 2, 82152 Martinsried, Germany. +49 (0)89 2180 74320. g.grupe@lrz.uni-muenchen.de

${ }^{5}$ School of Archaeology, University of Oxford, 36 Beaumont Street, Oxford OX1 2PG, UK. +44 (0)1865 278281. amy.bogaard@arch.ox.ac.uk

Stable isotope analysis of crop remains complements conventional isotope analysis of human and faunal bones, permitting a more holistic insight into subsistence practices in the past. Here, we demonstrate the insights that can be gained from crop isotope analysis by synthesising crop, faunal and human isotopic data from Linearbandkeramik villages, Late Neolithic lakeshore settlements and Early Iron Age sites in southwest Germany. As well as demonstrating the central role that plants played in the human diet, extensive stable isotope analysis of crop remains provides evidence for a strong interrelationship between crop production and consumption practices, which often belies a purely ecological motivation behind the differential treatment of crops.

Keywords: farming, Neolithic, Iron Age, stable isotopes, diet, crops, manuring Word count: 4920 (excluding references)

Introduction 
Understanding the interplay between production and consumption practices in the past is important for enhancing our understanding of prehistoric societies. In particular, it allows us to investigate how closely production practices and the labour involved in agricultural production were aligned with the social value of particular foods, and how this relationship changed through time. Examination of bioarchaeological remains_-including charred plant seeds and animal bones—has provided insights into what crops and livestock were consumed and how they were produced or raised (e.g. Bartosiewicz and Lillie, 2015; Jacomet, 2004; RowleyConwy and Legge, 2015). Arable weed seeds found in association with crop remains reflect cultivation conditions_-such as soil fertility and the degree to which the soil was worked-and can therefore provide information regarding the labour involved in crop production (Bogaard, 2004; Jones, 2002). Stable isotope values of human bones reflect the isotope values of the food groups that an individual consumed, offering a general but nonetheless direct insight into people’s dietary preferences. There are, however, relatively few techniques with the potential to allow us to explore directly how particular crop species were cultivated and how the labour that was involved in their production articulated with their culinary uses and their relative importance in the diet.

Stable isotope analysis of crop remains is a method that permits not only the reconstruction of past growing conditions, but can also contribute to a more accurate interpretation of human diet based on bone collagen isotope values. Since the charred cereal grains and pulse seeds are analysed directly, mixing of crops does not confound interpretation (e.g. Styring, Maier, et al., 2016), and the isotope values can be combined with other contextual evidence to reveal how different taxa were produced, stored and consumed. In this paper, we discuss the ways in which crop stable isotope analysis can provide a more holistic insight into past diet and agricultural practices, often belying ecological-based assumptions of how different crops were treated.

\section{Reconstructing diet}

Carbon and nitrogen isotope analysis of human and faunal bone collagen is now a routine way of estimating the relative importance of different food groups - terrestrial plants, animals, freshwater fish-in an individual's diet (e.g. DeNiro and Epstein, 
1981; Hedges and Reynard, 2007; Richards et al., 2003), relying on the premise that “you are what you eat, plus or minus a few per mil” (Ambrose and Norr, 1993). Carbon isotope $\left(\delta^{13} \mathrm{C}\right)$ values can reveal the relative importance of $\mathrm{C}_{3}$ and $\mathrm{C}_{4}$ plants in the diet (especially relevant in Europe once broomcorn millet is introduced in the Bronze Age; Motuzaite-Matuzeviciute et al., 2013), or the relative importance of marine and terrestrial resources (Schoeninger and DeNiro, 1984). Nitrogen isotope $\left(\delta^{15} \mathrm{~N}\right)$ values increase by between 2 and 6\%o with each trophic level (DeNiro and Epstein, 1981; Hare et al., 1991; Minagawa and Wada, 1984; O’Connell et al., 2012; Schoeninger and DeNiro, 1984), so that carnivores have $\delta^{15} \mathrm{~N}$ values 2-6\%o higher than herbivores. Consumers of fish-whose food chains tend to be longer than their terrestrial counterparts—-have higher $\delta^{15} \mathrm{~N}$ values still (Lee-Thorp, 2008). Having a direct means of assessing what types of resources people were actually consuming supplements archaeobotanical and archaeozoological analyses that provide insights into what plant and animal taxa were exploited and how they were processed and stored.

In archaeology, the conventional approach to reconstructing human diet is to determine the $\delta^{13} \mathrm{C}$ and $\delta^{15} \mathrm{~N}$ values of human bone collagen and compare these to those determined in faunal-usually herbivore-bone collagen from the same site or context (e.g. Hedges and Reynard, 2007; Reynard, 2015). An assumption is made that the plants consumed by herbivores and humans have the same $\delta^{15} \mathrm{~N}$ values, such that humans eating $100 \%$ plant protein have $\delta^{15} \mathrm{~N}$ values the same as associated herbivores and humans eating $100 \%$ animal protein will have $\delta^{15} \mathrm{~N}$ values $2-6 \%$ higher than these herbivores (Hedges and Reynard, 2007). There are a number of factors, however, that can result in variation in plant $\delta^{15} \mathrm{~N}$ values, including agricultural practices like manuring that are more likely to affect crops consumed by humans than wild plants consumed by herbivores (Bogaard et al., 2007, 2013). There is also a difference in the $\delta^{13} \mathrm{C}$ and $\delta^{15} \mathrm{~N}$ values of different plant parts, such that the cereal grains likely consumed by humans have higher $\delta^{13} \mathrm{C}$ and $\delta^{15} \mathrm{~N}$ values than the chaff by-product (rachis) that may have been fed to domestic animals (Fraser et al., 2011; Wallace et al., 2013). 
It is only in recent years that the $\delta^{13} \mathrm{C}$ and $\delta^{15} \mathrm{~N}$ values of charred cereal grains and pulse seeds recovered from archaeological sites have been directly determined and the results of these studies have invariably found that the $\delta^{15} \mathrm{~N}$ values of cereal grains are higher than those predicted from herbivore bone collagen $\delta^{15} \mathrm{~N}$ values (Bogaard et al., 2013; Fraser et al., 2013; Knipper et al., 2017; Lightfoot and Stevens, 2012; Nitsch et al., 2017; Styring, Maier, et al., 2016; Styring, Rösch, et al., 2017; Vaiglova et al., 2014). Unfortunately, it is still rare to find sufficient plant, animal and human remains preserved on the same archaeological site to attempt dietary reconstruction from isotope analysis of both plant and animal resources. Here we present data from Stuttgart-Mühlhausen Viesenhäuser Hof, a site in southwest Germany that was occupied in both the Neolithic and Early Iron Age, where this has been possible. This case study demonstrates the importance of including crop isotope values in dietary reconstruction, since both $\delta^{13} \mathrm{C}$ and $\delta^{15} \mathrm{~N}$ values of crops differ widely from those inferred for plants consumed by herbivores, and this can result in very different estimates of dietary contributions to people’s diet.

Reconstructing diet - the case study of Stuttgart-Mühlhausen Viesenhäuser Hof

Stuttgart-Mühlhausen Viesenhäuser Hof is a site in southwest Germany (Figure 1), which in the Linearbandkeramik (LBK) comprised a settlement located next to two extensive cemeteries, whose 177 identified burials have been investigated by Seitz (1989), Price et al. (2003) and Knipper et al. (in press). In the Early Iron Age the site was a village, with underground storage cellars and evidence for metalworking (Georgi, 2014). Carbon and nitrogen isotope analysis was carried out on human bones from the LBK cemetery and animal bones from the LBK settlement by Knipper et al. (in press). Knipper et al. (in press) found that men had higher $\delta^{15} \mathrm{~N}$ values than women, suggesting that men had access to higher amounts of animal protein than women at this time.

Here, we consider how the isotope values of charred cereal grain and pulse seed samples affect these interpretations. We have previously considered only the $\delta^{15} \mathrm{~N}$ values of the LBK crops, fauna and humans in an attempt to estimate the animal protein contribution to human diet, and the results of this dietary assessment can be 
found in Bogaard and Styring (2015). More recent carbon and nitrogen isotope analysis of human bones dating to the Early Iron Age at Stuttgart-Mühlhausen Viesenhäuser Hof (for more information see Müller-Scheeßel et al. in prep; data in Supplementary Table 1) also allows us to compare estimates of animal protein consumption between the LBK and the Early Iron Age at the same site. The $\delta^{13} \mathrm{C}$ and $\delta^{15} \mathrm{~N}$ values of crops and fauna from LBK and Early Iron Age Stuttgart-Mühlhausen Viesenhäuser Hof have been previously published in Styring et al. (2017: Appendices S5 and S6).

Figure 2a-b shows the $\delta^{13} \mathrm{C}$ and $\delta^{15} \mathrm{~N}$ values of human bone collagen from StuttgartMühlhausen Viesenhäuser Hof. The $\delta^{13} \mathrm{C}$ and $\delta^{15} \mathrm{~N}$ values of human bone collagen dating to the Early Iron Age are given in Supplementary Table 1. The expected distributions of $\delta^{13} \mathrm{C}$ and $\delta^{15} \mathrm{~N}$ values of individuals consuming $100 \%$ terrestrial animal products (milk and/or meat), cereal grains, pulses or wild plants are also shown (after Parnell et al., 2008). The error bars represent propagated standard deviations: a combination of the standard deviation of the determined isotope values for a particular food group ( $\delta^{13} \mathrm{Csd}$ and $\delta^{15} \mathrm{Nsd}$; Table 1$)$ and the uncertainty associated with consumer-diet offsets $\left(\Delta^{13} \mathrm{Csd}\right.$ and $\Delta^{15} \mathrm{Nsd}$; Table 1$)$. The expected $\delta^{13} \mathrm{C}$ and $\delta^{15} \mathrm{~N}$ value distribution of humans consuming $100 \%$ animal products is estimated by adding consumer-diet offsets of $1.0 \%$ (the approximate average of the $0.8-1.3 \%{ }^{13} \mathrm{C}$-enrichment of the bone collagen of carnivores over the bone collagen of their prey; Bocherens \& Drucker, 2003) and 4\%o (average of the $2-6 \%{ }^{15} \mathrm{~N}$ enrichment of consumers over their diet; DeNiro and Epstein, 1981; O’Connell et al., 2012) respectively, to the determined faunal bone collagen $\delta^{13} \mathrm{C}$ and $\delta^{15} \mathrm{~N}$ values for each time period. We have included all fauna-both wild and domestic herbivores and wild and domestic pigs - in these estimates because we assume that all of these species were exploited for their meat and/or milk.

The expected $\delta^{13} \mathrm{C}$ and $\delta^{15} \mathrm{~N}$ value distributions of $100 \%$ cereal grain, millet grain and pulse seed consumers are estimated by adding consumer-diet offsets of $4.8 \%$ o (the ${ }^{13} \mathrm{C}$-enrichment of bone collagen over diet estimated with a multiple linear model by Fernandes et al. (2012) for diets where there is a small difference in the $\delta^{13} \mathrm{C}$ value of protein and energy - i.e. in wild grasses and cereal crops; Tieszen, 1991) and 4\%o 
(average of the 2-6\% ${ }^{15} \mathrm{~N}$-enrichment of consumers over their diet; DeNiro and Epstein, 1981; O’Connell et al., 2012) respectively, to the determined cereal grain and pulse seed $\delta^{13} \mathrm{C}$ and $\delta^{15} \mathrm{~N}$ values for each time period. Recent work has found that charring results in a very slight increase in the carbon and nitrogen isotope values of cereal grains and pulse seeds, of $+0.11 \%$ in $\delta^{13} \mathrm{C}$ and $+0.31 \%$ in $\delta^{15} \mathrm{~N}$ values (Nitsch et al., 2015). The isotope values of the crop samples have been adjusted to account for this charring effect. In the absence of directly determined wild plant isotope values, the expected $\delta^{13} \mathrm{C}$ and $\delta^{15} \mathrm{~N}$ value distribution of $100 \%$ wild plant consumers is represented by the $\delta^{13} \mathrm{C}$ and $\delta^{15} \mathrm{~N}$ value distribution of wild and domestic herbivore bone collagen, since it can be assumed that herbivores consumed a mix of wild plants. The parameters used in the dietary estimates are given in Table 1.

It is clear from Figures 2a-b that the estimated $\delta^{13} \mathrm{C}$ and $\delta^{15} \mathrm{~N}$ values of $100 \%$ cereal grain consumers are significantly higher than the $\delta^{13} \mathrm{C}$ and $\delta^{15} \mathrm{~N}$ values of $100 \%$ wild plant consumers (equivalent to herbivores). In most reconstructions of human diet in the past, the isotope values of herbivores are assumed to represent humans consuming 100\% plants (not making the distinction between wild plants and crops). It is clear from this study that palaeodietary reconstruction based on this assumption would be very misleading and is likely to underestimate the role of cereals in the diet. The $\delta^{13} \mathrm{C}$ values of herbivore bone collagen may in fact be lower than the bone collagen $\delta^{13} \mathrm{C}$ values of humans consuming wild plant resources, since non-photosynthetic plant parts (such as nuts, fruits and tubers) most likely exploited by humans tend to have higher $\delta^{13} \mathrm{C}$ values than the leaves consumed by herbivores (Cernusak et al., 2009). Ideally, the isotope values of these wild resources would be determined directly but edible plant parts, such as fruits and nuts, are more rarely recovered in their charred form at agricultural sites than crops. For the Early Iron Age samples, the direct determination of crop $\delta^{13} \mathrm{C}$ values reveals that millet recovered from the site indeed comprised at least a small part of the human diet, since the $\delta^{13} \mathrm{C}$ values of the human bone collagen are enriched compared to the $\delta^{13} \mathrm{C}$ value distributions of $100 \%$ animal products, $\mathrm{C}_{3}$ cereal, pulse and wild plant consumers.

Although Figures 2a-b provides a visual representation of the likely importance of the different dietary components to the human diet, they do not make it clear that there is 
discrepancy in the digestible $\mathrm{C}$ and $\mathrm{N}$ contents of plant and animal resources. This means that in a quantitative estimate of human diet, plant foods may contribute a greater proportion than the visual picture suggests, due to their low nitrogen content. We have used the simmr statistical package in $\mathrm{R}$, a package designed to solve mixing equations for stable isotopic data within a Bayesian framework (Parnell et al., 2008), to estimate the relative proportions of animal products, cereal grains, pulses and wild plant foods in the human diet. This mixing model takes into account the standard deviation of the determined isotope values for a particular food group and the uncertainty associated with consumer-diet offsets (as in Figures 2a-b). It also adjusts the estimated dietary contribution of each food group based on its percentage of digestible $\mathrm{C}$ and $\mathrm{N}$ (see Table 1 for input values). Using this model, it is estimated that wild plant foods comprised the majority of the Neolithic diet (50 $\pm 5 \%$ ), animal products (meat and/or milk) comprised $18 \pm 4 \%$, and cultivated crops (cereals and pulses) comprised the rest (Figures 2c-d). In the Early Iron Age, the contribution of animal products ( $22 \pm 12 \%$ ) is estimated to have been similar to that in the Neolithic, but among the plant products, millet is estimated to have contributed $24 \pm 15 \%$ and wild plants a much lower $7 \pm 3 \%$ to the total diet. The estimated dietary contributions of each food resource with their standard deviation are given in Table 1 and boxplots of the dietary contributions are shown in Figures 2c-d. More detailed analysis of the outputs of the simmr model, including matrix plots showing the correlation between the contributions of different food sources, are provided in Supplementary Information.

As this example demonstrates, there are large uncertainties associated with estimating the contributions to human diet, even when the isotopic compositions of all but one of the potential food groups was determined. The high estimate of the dietary contribution of wild plants in the Neolithic is surprising; given the lack of directly measured wild plant foods, it should certainly be treated with caution. Similar dietary modelling at another LBK site in southwest Germany, Vaihingen an der Enz, suggests a more modest contribution of wild plant foods (29 $\pm 3 \%$ ) and higher contributions of crops (Styring, under review). Perhaps the safest inference that can be made about the dietary contribution of wild plant foods at Stuttgart Mühlhausen Viesenhäuser Hof is that it was, if anything, higher in the Neolithic than in the Iron Age. 
More broadly, inclusion of directly determined isotope values of cereal grains and pulses makes dietary predictions more robust than if the isotope values of only one food group (animal products) is included, as is the case in most palaeodietary reconstructions. Nitsch et al. (2017) presented a set of plausible and implausible dietary scenarios based on combinations of the isotopic compositions of eight food groups (barley, pulses, wheats, millet, cattle, sheep/goats/pigs, wild animals, fish) for the two Bronze Age communities of Archontiko and Thessaloniki Toumba in northern Greece (Figure 1). Such advanced statistical analysis illustrates the more nuanced interpretations that can be achieved by isotopic analysis of a more diverse range of food types and a large dataset. More progress may also be made with further investigation of consumer-diet offsets (O’Connell, 2017) and new methods such as amino acid isotope analysis, which does not rely on directly determining the isotopic composition of preserved food remains (Chikaraishi et al., 2014; Naito et al., 2013; Styring et al., 2015).

This rare crop, animal and human isotope dataset from two archaeological periods (LBK and Early Iron Age) at a single site also allows us to compare the ecological niches that these species occupied and identify how these differed between the Neolithic and the Early Iron Age. Figure 3 shows the raw isotope values of human and animal bone collagen and crop samples together with the 95\% prediction confidence ellipses for cereals (wheats and barley), pulses, animal protein and humans. There are no confidence ellipses for LBK pulses $(n=1)$ or Early Iron Age millet $(n=2)$ due to the low number of samples. Overlaying the confidence ellipses allows visual comparison of the location and spread of isotope values between the archaeological time periods (e.g. Grove and Pearson, 2014).

The clear overlap between the 95\% confidence ellipses of animal bone collagen isotope values from the Neolithic and the Early Iron Age in Figure 3 suggests that the isotope values of the animals' diets were relatively similar in the Neolithic and Early Iron Age and that either herding and foddering strategies remained relatively unchanged, or that any changes did not result in significant changes in the isotope values of the animals' diets. In contrast, the spread of cereal grain isotope values in the Early Iron Age is noticeably greater than the spread of cereal grain isotope values in the LBK. This isotopic diversity—particularly among barley grain samples—was 
noted by Styring, Rösch, et al. (2017) and was attributed to a wide variation in manuring levels between cultivation plots. This could reflect an extended gradient in manuring intensity due to the greater distance between settlements and animal penning areas within a larger Early Iron Age agricultural hinterland compared to the Neolithic. It is interesting to note that the spread of human isotope values in the Early Iron Age is also much greater than in the Neolithic, despite the lower number of samples, suggesting that cereals with their highly varied isotope values comprised a considerable portion of the Early Iron Age human diet.

Production and consumption: examining the interplay between agricultural practice and culinary roles

Determining the isotopic composition of crop remains can also provide insights into cultivation conditions and reveal how these correlate with storage, processing and consumption practices. Crop $\delta^{13} \mathrm{C}$ values reflect the degree of discrimination against ${ }^{13} \mathrm{C}$ during carbon fixation-primarily determined by their photosynthetic pathway: $\mathrm{C}_{3}, \mathrm{C}_{4}$ or $\mathrm{CAM}$ - and during movement of carbon dioxide into the leaves. The discrimination against ${ }^{13} \mathrm{C}$ during the movement of carbon dioxide into leaves differs between species (Richards and Condon, 1993), but is also influenced by environmental factors that include water availability-itself determined by factors including rainfall, temperature and humidity—and light intensity (Farquhar et al., 1989). While it is difficult to extrapolate past environmental conditions from crop $\delta^{13} \mathrm{C}$ values, it can be assumed that crop samples of the same taxa with similar $\delta^{13} \mathrm{C}$ compositions were grown in similar conditions.

Crop $\delta^{15} \mathrm{~N}$ values largely reflect the $\delta^{15} \mathrm{~N}$ value of the soil in which crops are grown, which itself reflects the $\delta^{15} \mathrm{~N}$ value of $\mathrm{N}$ inputs and subsequent effects of $\mathrm{N}$ cycling processes (e.g. Högberg, 1997). Processes such as clearing land by burning (Styring, Rösch, et al., 2017), seasonal waterlogging of soils (Finlay and Kendall, 2008) and high levels of organic $\mathrm{N}$ relative to plant demand (Aguilera et al., 2008) lead to preferential loss of ${ }^{14} \mathrm{~N}$, leaving ${ }^{15} \mathrm{~N}$-enriched nitrogen in the soil for plants to take up. In agricultural systems, a major influence on crop $\delta^{15} \mathrm{~N}$ values is the addition of ${ }^{15} \mathrm{~N}$ enriched manure. Studies of modern crops have found that manuring can increase 
cereal $\delta^{15} \mathrm{~N}$ values by as much as $10 \%$ across a range of locations and soils, according to the intensity_amount and frequency—of manuring (Fraser et al., 2011; Styring, Ater, et al., 2016). Manuring intensity_and this could include middening and composting - is therefore likely to override the effects of other variables, such as soil type and soil nitrogen content, on crop $\delta^{15} \mathrm{~N}$ values in farming systems (similar to the overriding effect of land use observed in Peukert et al., 2012 and Thornton et al., 2015).

The $\delta^{13} \mathrm{C}$ and $\delta^{15} \mathrm{~N}$ compositions of einkorn (Triticum monoccoccum), emmer ( $T$. diccoccum) and new type glume wheat grain samples recovered from a storage deposit at the LBK site of Vaihingen an der Enz and of einkorn and emmer grain samples from a storage deposit dating to the LBK/Middle Neolithic at StuttgartMühlhausen Viesenhäuser Hof are shown in Figure 4, outlined in black. These were published previously in Fraser et al. (2013) and Styring, Rösch, et al. (2017). Isotopic analysis of modern crops from single growing contexts (fields or plots) has shown that variability in $\delta^{13} \mathrm{C}$ and $\delta^{15} \mathrm{~N}$ values can be expected to be around $\pm 0.5 \%$ for carbon and $\pm 1 \%$ for nitrogen (95\% confidence intervals; Nitsch et al., 2015). At Vaihingen an der Enz and Stuttgart-Mühlhausen Viesenhäuser Hof, the 95\% confidence interval for $\delta^{13} \mathrm{C}$ values within each storage context is less than $0.4 \%$. Although the $95 \%$ confidence interval for $\delta^{15} \mathrm{~N}$ values from storage context 3 at Stuttgart-Mühlhausen Viesenhäuser Hof is slightly greater than might be expected from a single growing condition (1.2\%o based on two samples, compared to $1 \%$ ), it is less than $0.4 \%$ o for the other contexts. The similarity in isotopic compositions within storage deposits therefore suggests that emmer and einkorn (and potentially new type glume wheat at Vaihingen) were grown in the same field, as a maslin crop, at both sites (cf. Fraser et al., 2013). The difference between $\delta^{13} \mathrm{C}$ values of emmer and einkorn grains in the storage deposit at Stuttgart-Mühlhausen could reflect differences in their physiologies (e.g. ripening times). The cultivation of einkorn and emmer as a maslin crop had previously been suggested based on the fact that significant separate deposits of these glume wheat species have not been found on LBK sites (Knörzer and Gerlach, 1999; Kreuz et al., 2005; Willerding, 1980) and that mixed high-density grain-rich deposits have been found at sites such as Stuttgart-Mühlhausen Viesenhäuser Hof (Rösch, 1992) and Bietigheim-Bissingen (Piening, 1989). The crop 
isotope evidence from Stuttgart-Mühlhausen Viesenhäuser Hof complements that already published from Vaihingen an der Enz (Fraser et al., 2013), providing another indication that glume wheats were cultivated together in the Neolithic and possibly served the same culinary purpose.

The contrasting $\delta^{13} \mathrm{C}$ and $\delta^{15} \mathrm{~N}$ compositions of wheat and barley grain samples recovered from archaeological deposits that span almost a thousand years of occupation at the Late Neolithic site of Sipplingen Osthafen on the shore of Lake Constance (Figure 1) reveal that, in contrast to emmer and einkorn wheats, freethreshing wheat (Triticum durum/turgidum) and naked barley (Hordeum vulgare ssp. nudum) occupied different ecological niches at this site in the Neolithic that likely articulate with their distinct culinary uses. Figure 5 shows that free-threshing wheat grains had, on average, higher $\delta^{15} \mathrm{~N}$ values than barley grains for over a thousand years, which likely reflects cultivation conditions that involved higher inputs of manure/midden material (Styring, Maier, et al., 2016). Free-threshing wheat was also the predominant cereal species at Sipplingen until the beginning of the Horgen culture (c. 3300 BC), when it was replaced by emmer. It has therefore been interpreted that the higher level of manuring and associated labour inputs reflects the higher social status of naked wheat during the Pfyn culture (3870-3500 BC; Styring, Maier, et al., 2016). The marked increase in the $\delta^{15} \mathrm{~N}$ values of two glume wheat samples (one identified as emmer, the other as emmer/einkorn) in the Horgen compared to the Pfyn culture also correlates with an increase in the ubiquity of emmer, further supporting the theory that more manure was applied to more economically important crops. Due to the extraordinary level of organic preservation at the lakeshore villages on the shores of Lake Constance, we can also posit a relationship between cultivation practices and culinary use. Wheat was used to make porridge or a type of flatbread, whereas barley grains were likely roasted whole (Maier and Vogt, 2001). These results reveal differences in both the production and consumption of barley and wheat, hinting that the social value of these crop taxa permeated all stages of production.

\section{Challenging present-day preconceptions of past agricultural practice}


It is common to infer treatment of crops in the past from the ecological niches they occupy today. Barley, for example, is a hardy crop that is regarded as being able to tolerate relatively infertile conditions compared to wheat (Ceccarelli, 1994). It is therefore often hypothesised that barley in the past was grown with lower manure inputs than wheat, on land that was more marginal for agriculture (e.g. Rösch et al. 2014). The crop isotope evidence seems to correspond with these present-day practices at the Late Neolithic sites of Hornstaad-Hörnle IA and Sipplingen Osthafen in southwest Germany (Figure 1). As described above, free-threshing wheat grains had higher $\delta^{15} \mathrm{~N}$ values than barley grains for over a thousand years at Sipplingen Osthafen (Figure 5), likely reflecting higher manuring inputs (Styring, Maier, et al., 2016). At Hornstaad-Hörnle IA, the $\delta^{15} \mathrm{~N}$ values of naked barley (H. vulgare ssp. nudum) from individual households were relatively inconsistent compared to those of free-threshing wheat (T. durum/turgidum), implying that households were opportunistically growing their barley on small patches of land with different manuring histories (Styring, Maier, et al., 2016). This may reflect a lesser emphasis on managing the fertility of the soil in which barley was grown compared to that of wheat. A similar pattern—where the $\delta^{15} \mathrm{~N}$ values of free-threshing wheat ( $T$. aestivum/durum) are higher than those of hulled barley (H. vulgare) —was also observed at the Middle-Late Neolithic village of Kouphovouno in southern Greece (Vaiglova et al., 2014).

Stable isotope analysis of charred crop remains — namely six-row hulled barley $(H$. vulgare) and spelt wheat (T. spelta)_from the Early Iron Age sites of FreibergBeihingen, Stuttgart-Mühlhausen Viesenhäuser Hof, Eberdingen-Hochdorf, Kirchheim Osterholz Ipf-Zaunäcker and the Heuneburg in southwest Germany (Figure 1) paints a different picture, however. Figure 6 shows that the $\delta^{15} \mathrm{~N}$ values of six-row hulled barley are significantly higher than those of wheats at all five sites, revealing that barley fields received higher inputs of manure/household waste than wheat. As discussed in Styring, Rösch, et al. (2017), the more intensive manuring of barley is likely to have been connected to its importance for beer-brewing, which gave it a central role in elite feasting and drinking practices that shaped social relationships in the Early Iron Age. This demonstrates that in this Early Iron Age 
context, the decision to manure barley more than wheat likely had a social motivation, which does not correspond to the ecological niche that barley occupies today.

Higher $\delta^{15} \mathrm{~N}$ values of barley compared to wheat grains have also been observed at two Bronze Age sites (Archontiko and Thessaloniki Toumba) in northern Greece (Nitsch et al., 2017). It was posited that barley could have received more manure than wheat to provide 'early-bite' grazing pasture (Halstead, 2006). Equally, it was proposed that barley may have played an important role in human diet, since deposits of ground barley grains were discovered in multiple houses at the Early Bronze Age site of Archontiko (Valamoti et al., 2008). These final case studies thus demonstrate the value of crop isotope analysis in testing the theories relating to crop cultivation that may be inadvertently based on ecological extrapolation or present-day analogy.

\section{Conclusion}

Recent studies, including this one, that have incorporated crop isotope values into isotope-based reconstructions of past human diet (Fraser et al., 2013; Knipper et al., 2017; Nitsch et al., 2017; Styring et al., 2015; Styring, Charles, et al., 2017) have emphasised the centrality of crop foods in ancient diets. This underscores the importance of investigating the social and economic systems that were in place to produce staple crops if we are to better understand prehistoric communities. While contextual and isotopic evidence indicates the mixed cropping of glume wheats in the Early Neolithic in southwest Germany, differential manuring of naked wheat and naked barley for over a thousand years during the Late Neolithic articulated with their distinct culinary uses. Moreover, isotopic analysis of crops from Early Iron Age sites in southwest Germany demonstrates that the degree to which barley was manured was tied to its cultural importance within the wider society. Our results therefore reveal the strong interrelationship between production, storage and consumption of staple crops and demonstrate that crops often occupied different social and ecological niches than they do today.

These diverse findings also demonstrate the value of direct evidence in the study of past agricultural practices and warn against theories based on preconceptions. As Bogaard (2015) has pointed out, hypotheses based on the combination of multiple 
lines of evidence are much more robust than those based on just one. Isotope analysis of ancient crops complements other bioarchaeological proxies to provide a clearer insight into the nuanced behaviour that was intertwined with agricultural production and diet in the past.

\section{Acknowledgements}

The work reported here was supported by the European Research Council (AGRICURB project, grant no. 312785, PI: Bogaard) and the German Research Foundation (Isotope analyses of Iron Age individuals from Stuttgart-Mühlhausen Viesenhäuser Hof, grant no. MU3053/1, PI: Müller-Scheeßel). 


\section{References}

Aguilera, M., Araus, J.L., Voltas, J., Rodríguez-Ariza, M. and Molina, F. (2008) Stable carbon and nitrogen isotopes and quality traits of fossil cereal grains provide clues on sustainability at the beginnings of Mediterranean agriculture. Rapid Communications in Mass Spectrometry 22(11): 1653-1663.

Ambrose, S.H. and Norr, L. (1993) Experimental evidence for the relationship of the carbon isotope ratios of whole diet and dietary protein to those of bone collagen and carbonate. In: Lambert, J.B. and Grupe, G. (eds.), Prehistoric Human Bone. Archaeology at the Molecular Level, Berlin: Springer-Verlag, pp. 1-37.

Bartosiewicz, L. and Lillie, M. (2015) Subsistence practices in central and eastern Europe. In: Fowler, C., Harding, J. and Hofmann, D. (eds.), The Oxford Handbook of Neolithic Europe, Oxford: Oxford University Press, pp. 411428.

Bocherens, H. and Drucker, D. (2003) Trophic level isotopic enrichment of carbon and nitrogen in bone collagen: case studies from recent and ancient terrestrial ecosystems. International Journal of Osteoarchaeology 13, 46-53.

Bogaard, A. (2004) Neolithic farming in central Europe. London: Routledge.

Bogaard, A. (2015) Lessons from modeling Neolithic farming practice: methods of elimination. In: Chapman, R. and Wylie, A. (eds.), Material Evidence: Learning from Archaeological Practice, London: Routledge, pp. 243-254.

Bogaard, A. and Styring, A.K. (2015) Plants, people and diet in the Neolithic of western Eurasia. In: Lee-Thorp, J. and Katzenberg, M.A. (eds.), The Oxford Handbook of the Archaeology of Diet, Oxford: Oxford University Press.

Bogaard, A., Heaton, T.H.E., Poulton, P. and Merbach, I. (2007) The impact of manuring on nitrogen isotope ratios in cereals: archaeological implications for reconstruction of diet and crop management practices. Journal of Archaeological Science 34: 335-343.

Bogaard, A., Fraser, R., Heaton, T.H.E., Wallace, M., Vaiglova, P., Charles, M., Jones, G., Evershed, R.P., Styring, A.K., Andersen, N., Arbogast, R.-M., Bartosiewicz, L., Gardeisen, A., Kanstrup, M., Maier, U., Marinova, E., Ninov, L., Schäfer, M. and Stephan, E. (2013) Crop manuring and intensive land management by Europe's first farmers. Proceedings of the National Academy of Sciences 110: 12589-12594. 
Ceccarelli, S. (1994) Specific adaptation and breeding for marginal conditions. Euphytica 77(3): 205-219.

Cernusak, L.A., Tcherkez, G., Keitel, C., Cornwell, W., Santiago, L.S., Knohl, A., Barbour, M., Williams, D., Reich, P.B., Ellsworth, D., Dawson, T.E., Griffiths, H., Farquhar, G.D. and Wright, I.J. (2009) Why are nonphotosynthetic tissues generally ${ }^{13} \mathrm{C}$ enriched compared with leaves in $\mathrm{C}_{3}$ plants? Review and synthesis of current hypotheses. Functional Plant Biology 36: 199-213.

Chikaraishi, Y., Steffan, S.A., Ogawa, N.O., Ishikawa, N., Sasaki, Y., Tsuchiya, M. and Ohkouchi, N. (2014) High-resolution food webs based on nitrogen isotopic composition of amino acids. Ecology and Evolution 4: 2423-2449.

DeNiro, M.J. and Epstein, S. (1981) Influence of diet on the distribution of nitrogen isotopes in animals. Geochimica et Cosmochimica Acta 45: 341-351.

Farquhar, G.D., Ehleringer, J.R. and Hubick, K.T. (1989) Carbon isotope discrimination and photosynthesis. Annual Review of Plant Physiology and Plant Molecular Biology 40: 503-537.

Fernandes, R., Nadeau, M.-J., Grootes, P.M., (2012). Macronutrient-based model for dietary carbon routing in bone collagen and bioapatite. Archaeological and Anthropological Sciences 4, 291-301.

Finlay, J.C. and Kendall, C. (2008) Stable isotope tracing of temporal and spatial variability in organic matter sources to freshwater ecosystems. In: Michener, R. and Lajtha, K. (eds.), Stable Isotopes in Ecology and Environmental Science, Oxford: Blackwell Publishing Ltd., pp. 283-333.

Fraser, R.A., Bogaard, A., Heaton, T., Charles, M., Jones, G., Christensen, B.T., Halstead, P., Merbach, I., Poulton, P., Sparkes, D. and Styring, A.K. (2011) Manuring and stable nitrogen isotope ratios in cereals and pulses: towards a new archaeobotanical approach to the inference of land use and dietary practices. Journal of Archaeological Science 38: 2790-2804.

Fraser, R.A., Bogaard, A., Schäfer, M., Arbogast, R.-M. and Heaton, T.H.E. (2013) Integrating botanical, faunal and human stable carbon and nitrogen isotope values to reconstruct land use and palaeodiet at LBK Vaihingen an der Enz, Baden-Württemberg. World Archaeology 45: 492-517. 
Georgi, M. (2014) Die mittelneolithischen Siedlungsreste vom Viesenhäuser Hof, Stuttgart Mühlhausen - Auswertung der Befunde und Keramik der Grabung 1991-1993. Fundberichte aus Baden-Württemberg 34: 7-142.

Grove, M. and Pearson, J. (2014) Visualisation and permutation methods for archaeological data analysis. Archaeological and Anthropological Sciences 6: 319-328.

Halstead, P. (2006) Sheep in the garden: the integration of crop and livestock husbandry in early farming regimes of Greece and southern Europe. In: Serjeantson, D. and Field, D. (eds), Animals in the Neolithic of Britain and Europe, Oxford: Oxbow Books, pp. 42-55.

Hare, P.E., Fogel, M.L., Stafford Jr., T.W., Mitchell, A.D. and Hoering, T.C. (1991) The isotopic composition of carbon and nitrogen in individual amino acids isolated from modern and fossil proteins. Journal of Archaeological Science 18: 277-292.

Hedges, R.E.M. and Reynard, L.M. (2007) Nitrogen isotopes and the trophic level of humans in archaeology. Journal of Archaeological Science 34: 1240-1251.

Högberg, P. (1997) Tansley Review No. 95. ${ }^{15} \mathrm{~N}$ natural abundance in soil-plant systems. New Phytologist 137: 179-203.

Jacomet, S. (2004) Archaeobotany: a vital tool in the investigation of lake-dwellings. In: Menotti, F. (ed.), Living on the Lake in Prehistoric Europe: 150 Years of Lake-dwelling Research, London: Routledge, pp. 162-177.

Jones, G. (2002) Weed ecology as a method for the archaeobotanical recognition of crop husbandry practices. Acta Palaeobotanica 42: 185-193.

Knipper, C., in press. Kohlenstoff- und Stickstoff-Isotopenanalysen an bandkeramischen Bestattungen vom “Viesenhäuser Hof” bei StuttgartMühlhausen: Implikationen zur Ernährungsrekonstruktion, Geschlechtsspezifik und Siedlungsdynamik. In: Meyer, C., Held, P., Knipper, C., Nicklisch, N. (eds.), Der Zahn der Zeit. Mensch und Kultur im Spiegel interdisziplinärer Forschung. Festschrift für Kurt W. Alt. Halle: Landesamt für Denkmalpflege und Archäologie Sachsen-Anhalt.

Knipper, C., Pichler, S.L., Rissanen, H., Stopp, B., Kühn, M., Spichtig, N., Röder, B., Schibler, J., Lassau, G. and Alt, K.W. (2017) What is on the menu in a Celtic town? Iron Age diet reconstructed at Basel-Gasfabrik, Switzerland. Archaeological and Anthropological Sciences 9: 1307-1326. 
Knörzer, K.-H. and Gerlach, R. (1999) Geschichte der Nahrungs- und Nutzpflanzen im Rheinland. In: Knörzer, K.-H. and Beyer, B. (eds.), Pflanzenspuren Archäobotanik im Rheinland: Agrarlandscahft und Nutzpflanzen im Wandel der Zeiten, Cologne: Rheinland-Verlag GmbH, pp. 67-127.

Kreuz, A., Marinova, E., Schäfer, E. and Wiethold, J. (2005) A comparison of early Neolithic crop and weed assemblages from the Linearbandkeramik and the Bulgarian Neolithic cultures: differences and similarities. Vegetation History and Archaeobotany 14: 237-258.

Lee-Thorp, J.A. (2008) On isotopes and old bones. Archaeometry 50: 925-950.

Lightfoot, E. and Stevens, R.E. (2012) Stable isotope investigations of charred barley (Hordeum vulgare) and wheat (Triticum spelta) grains from Danebury Hillfort: implications for palaeodietary reconstructions. Journal of Archaeological Science 39: 656-662.

Maier, U. and Vogt, R. (2001) Siedlungsarchäologie im Alpenvorland VI. Forschungen und Berichte zur Vor- und Frühgeschichte in BadenWürttemberg 74, Stuttgart: Konrad Theiss Verlag.

Minagawa, M. and Wada, E. (1984) Stepwise enrichment of ${ }^{15} \mathrm{~N}$ along food chains: Further evidence and the relation between $\delta^{15} \mathrm{~N}$ and animal age. Geochimica et Cosmochimica Acta 48: 1135-1140.

Motuzaite-Matuzeviciute, G., Staff, R.A., Hunt, H.V., Liu, X. and Jones, M.K. (2013) The early chronology of broomcorn millet (Panicum miliaceum) in Europe. Antiquity 87: 1073-1085.

Naito, Y.I., Chikaraishi, Y., Ohkouchi, N. and Yoneda, M. (2013) Evaluation of carnivory in inland Jomon hunter-gatherers based on nitrogen isotopic compositions of individual amino acids in bone collagen. Journal of Archaeological Science 40: 2913-2923.

Nitsch, E.K., Andreou, S., Creuzieux, A., Gardeisen, A., Halstead, P., Isaakidou, V., Karathanou, A., Kotsachristou, D., Nikolaidou, D., Papanthimou, A., Petridou, C., Triantaphyllou, S., Valamoti, S.M., Vasileiadou, A. and Bogaard, A. (2017) A bottom-up view of food surplus: using stable carbon and nitrogen isotope analysis to investigate agricultural strategies and diet at Bronze Age Archontiko and Thessaloniki Toumba, northern Greece. World Archaeology 49: 105-137. 
Nitsch, E.K., Charles, M. and Bogaard, A. (2015) Calculating a statistically robust $\delta^{13} \mathrm{C}$ and $\delta^{15} \mathrm{~N}$ offset for charred cereal and pulse seeds. Science and Technology of Archaeological Research 1: 1-8.

O’Connell, T.C. (2017) 'Trophic' and 'source' amino acids in trophic estimation: a likely metabolic explanation. Oecologia 184: 317-326.

O’Connell, T.C., Kneale, C.J., Tasevska, N. and Kuhnle, G.G.C. (2012) The dietbody offset in human nitrogen isotopic values: A controlled dietary study. American Journal of Physical Anthropology 149: 426-434.

Parnell, A.C., Inger, R., Bearhop, S. and Jackson, A.L. (2008) SIAR: stable isotope analysis in R. Available from: http://cran.r-project.org/web/packages/ siar/index.html.

Peukert, S., Bol, R., Roberts, W., Macleod, C.J.A., Murray, P.J., Dixon, E.R. and Brazier, R.E. (2012) Understanding spatial variability of soil properties: a key step in establishing field- to farm-scale agro-ecosystem experiments. Rapid Communications in Mass Spectrometry 26: 2413-2421.

Piening, U. (1989) Pflanzenresete aus der bandkeramischen Siedlung von BietigheimBissingen, Kreis Ludwigsburg. Fundberichte aus Baden-Württemberg 14: 119-140.

Price, T.D., Wahl, J., Knipper, C., Burger-Heinrich, E., Kurtz, G., Bentley, R.A., (2003). Das bandkeramische Gräberfeld vom „Viesenhäuser Hof“ bei Stuttgart-Mühlhausen: Neue Untersuchungsergebnisse zum Migrationsverhalten im frühen Neolithikum. In: Fundberichte Aus BadenWürttemberg. Stuttgart: Konrad Theiss Verlag, pp. 23-58.

Reynard, L. (2015) How 'best' to determine trophic levels in archaeological agricultural communities. In: Lee-Thorp J and Katzenberg MA (eds.), The Oxford Handbook of the Archaeology of Diet, Oxford: Oxford University Press.

Richards, M.P., Schulting, R.J. and Hedges, R.E.M. (2003) Archaeology: Sharp shift in diet at onset of Neolithic. Nature 425: 366-366.

Richards, R.A. and Condon, A.G. (1993) Challenges ahead in using carbon isotope discrimination in plant-breeding programs. In: Ehleringer, J.R., Hall, A.E. and Farquhar, G.D. (eds), Stable Isotopes and Plant Carbon-Water Relations, London: Academic Press, pp. 451-464. 
Rösch, M. (1992) Zwei pflanzenhaltige Gruben der Linearbandkeramik vom Viesenhäuser Hof, Stuttgart-Mühlhausen. Archälogische Ausgrabungen in Baden-Württemberg 1991: 53-56.

Rösch, M., Kleinmann, A., Lechterbeck, J. and Wick, L. (2014). Botanical off-site and on-site data as indicators of different land use systems: a discussion with examples from Southwest Germany. Vegetation History and Archaeobotany 23: $121-133$.

Rowley-Conwy, P.A. and Legge, A.J. (2015) Subsistence Practices in Western and Northern Europe. In: Fowler, C., Harding, J. and Hofmann, D. (eds), The Oxford Handbook of Neolithic Europe, Oxford: Oxford University Press, pp. 429-446.

Schoeninger, M.J. and DeNiro, M.J. (1984) Nitrogen and carbon isotopic composition of bone collagen from marine and terrestrial animals. Geochimica et Cosmochimica Acta 48: 625-639.

Seitz, M. (1989) Das bandkeramische Gräberfeld von Stuttgart-Mühlhausen, Viesenhäuser Hof - Befunde und Funde. (unpublished Masters thesis). Tübingen.

Styring (under review) Beyond what the eye can see: the potential of scientific methods in reconstructing past subsistence practices in Africa. In: Eichhorn, B. and Höhn, A. (eds), Of Trees, Grasses and Crops - Man and Vegetation Change in Sub-Saharan Africa and Beyond.

Styring, A.K., Fraser, R.A., Arbogast, R.-M., Halstead, P., Isaakidou, V., Pearson, J.A., Schäfer, M., Triantaphyllou, S., Valamoti, S.M., Wallace, M., Bogaard, A. and Evershed, R.P. (2015) Refining human palaeodietary reconstruction using amino acid $\delta^{15} \mathrm{~N}$ values of plants, animals and humans. Journal of Archaeological Science 53: 504-515.

Styring, A.K., Maier, U., Stephan, E., Schlichtherle, H. and Bogaard, A. (2016) Cultivation of choice: new insights into farming practices at Neolithic lakeshore sites. Antiquity 349: 95-110.

Styring, A.K., Ater, M., Hmimsa, Y., Fraser, R.A., Miller, H., Neef, R., Pearson, J.A. and Bogaard, A. (2016) Disentangling the effect of farming practice from aridity on crop stable isotope values: A present-day model from Morocco and its application to early farming sites in the eastern Mediterranean. The Anthropocene Review 3: 2-22. 
Styring, A.K., Rösch, M., Stephan, E., Stika, H.-P., Fischer, E., Sillmann, M. and Bogaard, A. (2017) Centralisation and long-term change in farming regimes: comparing agricultural practices in Neolithic and Iron Age south-west Germany. Proceedings of the Prehistoric Society.

Styring, A.K., Charles, M., Fantone, F., Hald, M.-M., McMahon, A., Meadow, R.H., Nicholls, G.K., Patel, A.J., Pitre, M.C., Smith, A., Sołtysiak, A., Stein, G., Weber, J.A., Weiss, H. and Bogaard, A. (2017) Isotope evidence for agricultural extensification reveals how the world's first cities were fed. Nature Plants 3: 17076.

Thornton, B., Martin, G., Procee, M., Miller, D.R., Coull, M., Yao, H., Chapman, S.J., Hudson, G. and Midwood, A.J. (2015) Distributions of carbon and nitrogen isotopes in Scotland's topsoil: a national-scale study. European Journal of Soil Science 66: 1002-1011.

Tieszen, L.L. (1991) Natural variations in the carbon isotope values of plants: Implications for archaeology, ecology, and paleoecology. Journal of Archaeological Science 18, 227-248.

Vaiglova, P., Bogaard, A., Collins, M., Cavanagh, W., Mee, C., Renard, J., Lamb, A., Gardeisen, A. and Fraser, R.A. (2014) An integrated stable isotope study of plants and animals from Kouphovouno, southern Greece: a new look at Neolithic farming. Journal of Archaeological Science 42: 201-215.

Valamoti, S.M., Papanthimou, A. and Pilali, A. (2008) Cooking ingredients from Bronze Age Archontiko: the archaeobotanical evidence. In: Facorellis, Y., Zacharias, N., and Polikreti, K. (eds.), Proceedings of the Symposium of the Hellenic Society for Archaeometry: National Hellenic Research Foundation, Athens 28-31 May, 2003, Oxford: British Archaeological Reports.

Wallace, M., Jones, G., Charles, M., Fraser, R.A., Halstead, P., Heaton, T.H.E. and Bogaard, A. (2013) Stable carbon isotope analysis as a direct means of inferring crop water status and water management practices. World Archaeology 45: 388-409.

Willerding, U. (1980) Zum Ackerbau der Bandkeramiker. Materialhefte zur Ur- und Frühgeschichte Niedersachsens 16: 421-456. 


\section{$\underline{\text { Figure Captions }}$}

Figure 1. Map of Europe showing the location of archaeological sites mentioned in the text.

Figure 2. a) and b). Human bone collagen $\delta^{13} \mathrm{C}$ and $\delta^{15} \mathrm{~N}$ values from a) LBK and b) Early Iron Age Stuttgart-Mühlhausen Viesenhäuser Hof plotted in relation to the expected distributions (mean \pm 2 s.d.) of $\delta^{13} \mathrm{C}$ and $\delta^{15} \mathrm{~N}$ values of individuals consuming 100\% animal products (milk and/or meat), cereal grains, pulses and wild plants. These distributions are estimated from directly determined $\delta^{13} \mathrm{C}$ and $\delta^{15} \mathrm{~N}$ values of faunal bone collagen, cereal grains and pulse seeds from each time period. The expected $\delta^{13} \mathrm{C}$ and $\delta^{15} \mathrm{~N}$ value distributions of $100 \%$ wild plant consumers are equal to those of wild herbivore bone collagen, since wild herbivores are assumed to have consumed only wild plants. Figure 2 c) and d). The estimated proportions of animal products (milk and/or meat), cereal grains, pulses and wild plants to the c) LBK and d) Early Iron Age human diet as estimated using the simmr model (Parnell et al., 2008). Human bone collagen isotope values from the LBK have been published previously in Knipper et al. (in press) and the faunal bone collagen, cereal grain and pulse seed isotope values have been published previously in Styring et al. (2017).

Figure 3. Isotope values of human and animal bone collagen and crop samples from LBK and Early Iron Age Stuttgart-Mühlhausen Viesenhäuser Hof, together with the 95\% prediction confidence ellipses for cereals (wheats and barley), pulses, animal protein and humans. Faunal symbols with black borders indicate fauna dating to the Neolithic period, faunal symbols without borders indicate those dating to the Early Iron Age. Human bone collagen isotope values from the LBK have been published previously in Knipper et al. (in press) and the faunal bone collagen, cereal grain and pulse seed isotope values have been published previously in Styring et al. (2017).

Figure 4. $\delta^{13} \mathrm{C}$ and $\delta^{15} \mathrm{~N}$ values of cereal grain samples from a) Vaihingen an der Enz and b) Stuttgart-Mühlhausen Viesenhäuser Hof. Grain samples from the same storage context are outlined in black. Cereal grain isotope values from Vaihingen an der Enz have been published previously in Fraser et al. (2013) and cereal grain isotope values 
from Stuttgart-Mühlhausen Viesenhäuser Hof have been published previously in Styring et al. (2017).

Figure 5. $\delta^{15} \mathrm{~N}$ values of cereal grain samples spanning the Pfyn and Horgen cultures at Sipplingen Osthafen, southwest Germany. These crop isotope values have been published previously in Styring et al. (2016).

Figure 6. $\delta^{15} \mathrm{~N}$ values of barley and wheat grain samples from five Early Iron Age sites in southwest Germany. These crop isotope values have been published previously in Styring et al. (2017).

Table 1. Mean average $\delta^{13} \mathrm{C}$ and $\delta^{15} \mathrm{~N}$ values of human bone collagen, fauna bone collagen, cereal grains, pulse seeds and wild plants (estimated from herbivore bone collagen) from LBK and Early Iron Age Stuttgart Mühlhausen Viesenhäuser Hof used in dietary estimates. The propagated standard deviation (sd) of these average $\delta^{13} \mathrm{C}$ and $\delta^{15} \mathrm{~N}$ values are a combination of the standard deviation of the determined isotope values for a particular food group ( $\delta^{13} \mathrm{Csd}$ and $\left.\delta^{15} \mathrm{Nsd}\right)$ and the uncertainty associated with consumer-diet offsets ( $\Delta^{13} \mathrm{Csd}$ and $\left.\Delta^{15} \mathrm{Nsd}\right)$. The contributions of animal products, cereals, pulses and wild plant foods, as estimated using the simmr model, are also given. 
Table 1.

\begin{tabular}{|c|c|c|c|c|c|c|c|c|c|c|c|c|c|c|c|c|c|c|}
\hline \multirow[b]{3}{*}{ Period } & \multirow[b]{3}{*}{ Group } & \multirow[b]{3}{*}{$n$} & \multirow[b]{3}{*}{$\begin{array}{c}\text { Mean } \delta^{13} \mathrm{C} \\
(\% \text { o) }\end{array}$} & \multirow[b]{3}{*}{$\delta^{13} \mathrm{Csd}$} & \multirow[b]{3}{*}{$\begin{array}{c}\Delta{ }^{13} \mathrm{C}_{\text {consumer-diet }} \\
(\%)^{1}\end{array}$} & \multirow[b]{3}{*}{$\Delta^{13} \operatorname{Csd}^{2}$} & \multirow[b]{3}{*}{ Propagated sd } & \multirow[b]{3}{*}{$\begin{array}{c}\text { Mean } \\
\delta^{15} \mathrm{~N}(\%)\end{array}$} & \multirow[b]{3}{*}{$\delta^{15} \mathrm{Nsd}$} & \multirow[b]{3}{*}{$\begin{array}{c}\Delta{ }^{15} \mathrm{~N}_{\text {consumer-diet }} \\
(\%)^{3}\end{array}$} & \multirow[b]{3}{*}{$\Delta^{15} \mathrm{Nsd}^{2}$} & \multirow[b]{3}{*}{ Propagated sd } & \multirow[b]{3}{*}{$\begin{array}{c}\text { Digestible C } \\
(\%)^{5}\end{array}$} & \multirow[b]{3}{*}{$\begin{array}{c}\text { Digestible N } \\
(\%)^{5}\end{array}$} & \multicolumn{4}{|c|}{ Estimated dietary contribution (\%) } \\
\hline & & & & & & & & & & & & & & & \multirow[b]{2}{*}{ Mean } & \multirow[b]{2}{*}{ sd } & \multirow{2}{*}{\multicolumn{2}{|c|}{$95 \%$ credible interval }} \\
\hline & & & & & & & & & & & & & & & & & & $97.5 \%$ \\
\hline Neolithic & Humans & 41 & -20.6 & 0.2 & NA & $\mathrm{NA}$ & NA & 9.7 & 0.5 & NA & NA & NA & NA & NA & NA & $\mathrm{NA}$ & NA & $\overline{\mathrm{NA}}$ \\
\hline Neolithic & Terrestrial fauna & 11 & -21.4 & 0.6 & 1 & 1 & 1.17 & 7.6 & 0.8 & 4 & 1 & 1.29 & 51.5 & 12 & 18 & 4 & 11 & 27 \\
\hline Neolithic & Cereals & 16 & -23.5 & 0.5 & 4.8 & 1 & 1.11 & 6.2 & 0.8 & 4 & 1 & 1.26 & 42 & 3.5 & 16 & 6 & 5 & $2 \varepsilon$ \\
\hline Neolithic & Pulses & 1 & -23.5 & - & 4.8 & 1 & 1.00 & 2.9 & - & 4 & 1 & 1.00 & 42 & 8 & 16 & 5 & 8 & 25 \\
\hline Neolithic & Wild plants ${ }^{4}$ & 6 & -26.3 & 0.8 & 4.8 & 1 & 1.31 & 3.4 & 0.8 & 4 & 1 & 1.28 & 44 & 1 & 50 & 5 & 41 & $5 s$ \\
\hline Early Iron Age & Humans & 6 & -19.7 & 0.5 & NA & NA & NA & 9.1 & 1.3 & NA & NA & NA & NA & NA & NA & NA & NA & NA \\
\hline Early Iron Age & Terrestrial fauna & 22 & -21.4 & 0.7 & 1 & 1 & 1.24 & 6.8 & 0.9 & 4 & 1 & 1.37 & 51.5 & 12 & 23 & 12 & 3 & 50 \\
\hline Early Iron Age & Cereals & 29 & -24.7 & 0.8 & 4.8 & 1 & 1.29 & 6.8 & 1.8 & 4 & 1 & 2.05 & 42 & 3.5 & 26 & 16 & 3 & 63 \\
\hline Early Iron Age & Pulses & 7 & -25.7 & 0.5 & 4.8 & 1 & 1.10 & 2.0 & 0.5 & 4 & 1 & 1.13 & 42 & 8 & 20 & 12 & 3 & 46 \\
\hline Early Iron Age & Millet & 2 & -11.5 & 0.8 & 4.8 & 1 & 1.30 & 6.0 & 0.5 & 4 & 1 & 1.12 & 42 & 3.5 & 24 & 15 & 3 & 56 \\
\hline Early Iron Age & Wild plants ${ }^{4}$ & 17 & -26.5 & 0.7 & 4.8 & 1 & 1.24 & 2.8 & 0.9 & 4 & 1 & 1.33 & 44 & 1 & 7 & 3 & 1 & 13 \\
\hline
\end{tabular}

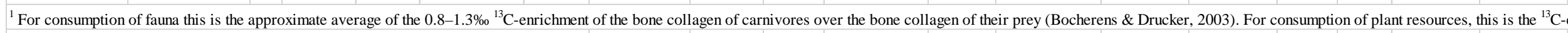
${ }^{2}$ Generous estimate of the standard deviation associated with consumer-diet offsets

${ }^{3}$ Average of the $2-6 \%{ }^{15} \mathrm{~N}$-enrichment of consumers over their diet (DeNiro and Epstein, 1981; O'Connell et al., 2012)

${ }^{4}$ Estimated by subtracting consumer-diet offsets from determined herbivore bone collagen $\delta^{13} \mathrm{C}$ and $\delta^{15} \mathrm{~N}$ values

${ }^{5} \% \mathrm{C}$ and $\% \mathrm{~N}$ of animal products and wild plants taken from Phillips and Koch (2002); cereals and pulses taken from Nitsch et al. (2017) 